\title{
Prevalence of High-Risk Genotypes of Human Papillomavirus: Women Diagnosed with Premalignant and Malignant Pap Smear Tests in Southern Ecuador
}

\author{
Paola Dalgo Aguilar, ${ }^{1}$ Cisne Loján González, ${ }^{2}$ Ana Córdova Rodríguez, ${ }^{1}$ \\ Katherine Acurio Páez, ${ }^{2}$ Ana Paulina Arévalo, ${ }^{1}$ and Jana Bobokova ${ }^{1}$ \\ ${ }^{1}$ Departamento de Ciencias de la Salud, Sección Genética Humana, Microbiología y Bioquímica Clínica, \\ Universidad Técnica Particular de Loja, Loja, Ecuador \\ ${ }^{2}$ Sociedad de Lucha Contra el Cáncer, Hospital SOLCA Núcleo de Loja, Loja, Ecuador
}

Correspondence should be addressed to Paola Dalgo Aguilar; pxdalgo@utpl.edu.ec

Received 2 March 2017; Accepted 23 May 2017; Published 22 June 2017

Academic Editor: Diane M. Harper

Copyright ( 2017 Paola Dalgo Aguilar et al. This is an open access article distributed under the Creative Commons Attribution License, which permits unrestricted use, distribution, and reproduction in any medium, provided the original work is properly cited.

\begin{abstract}
Human papillomavirus (HPV) is the primary infectious agent for the development of cervical cancer, although the presence of the virus alone is insufficient for viral development and proliferation; this can be attributed to the increase in potential oncogenic risk, along with other risk factors. In the present investigation, the prevalence of high-risk HPV was determined from samples of premalignant or malignant cervical cytology in women from the southern region of Ecuador. The kit we used was able to detect genotypes $16,18,31,33,35,39,45,51,52,56,58$, and 59 . In addition, $64.5 \%$ of the analyzed samples were positive for HPV, with genotypes 16 and 18 being the most prevalent (16 was detected in 148 samples and 18 in 108). Genotypes 58 and 51 were the third most frequent simple and multiple infections, respectively. The data are very similar to those obtained worldwide, suggesting that the strategy of sex education, and the use of vaccines as primary prevention agents, could significantly decrease the incidence and mortality rate of cervical cancer in the southern region of Ecuador.
\end{abstract}

\section{Introduction}

According to data estimated for 2012, cervical cancer was the fifth most common type worldwide, behind breast, prostate, lung, and colorectal cancer. In the female population, it ranks fourth in incidence and mortality, with about 528,000 new cases and 266,000 deaths per year [1].

Data from the National Institute of Statistics and Censuses of Ecuador (INEC) that year found that cervical cancer was the second cause of death in women, due to oncological disease, with about 697 deaths, after stomach cancer [2].

In the southern region of the country, in the province of Loja, cervical cancer was reported as the most common cancer in women, with a total of 844 new cases diagnosed between 1997 and 2006. Loja province corresponds to 422 new cases, representing $23.1 \%$ of all malignant tumors in women. Of these 422 cases, 182 (43.1\%) were carcinomas in situ. The standardized rate of the global incidence of invasive cervical cancer in this region was $31.5 \times 100,000$ inhabitants; in the case of in situ cancer, it was $23.8 \times 100,000$ inhabitants. Cervical cancer is also the number one cause of female death in the city of Loja, due to oncological disease, with a standardized rate of $9.6 \times 100,000$ inhabitants, identifying this disease as a major health problem in the southern region of Ecuador [3].

HPV is considered the main risk factor for the development of cervical cancer [4-7]. It is estimated that more than $50-75 \%$ of sexually active women are infected with one or more HPV genotypes throughout their lives $[8,9]$. Once the infection occurs, the immune system achieves spontaneous regression $[10,11]$ in $80-90 \%$ of cases after $18-24$ months $[8,12-14]$. In this way, it is demonstrated that HPV infection is a necessary but insufficient reason for development of cancer $[15,16]$. 
More than 150 HPV genotypes have been described. Approximately 40 of them have a special tropism via the anogenital and mucosal region [17-20]. They are classified into high oncogenic risk groups $(16,18,31,33,34,35,39,45,51$, $52,56,58,59$, and 68$)$, possible oncogenic risk $(26,30,34,53$, $66,67,69,70,73,82,85$, and 97 ), and low-risk group that cause benign lesions like cervical warts or condylomas $(6,11,28,32$, $44,43,44,54,55,57,61,62,71,72,74,81,83,84,86,87$, and 89 ) $[6,20-24]$. Among high-risk genotypes, the most common worldwide are 16 and 18, accounting for approximately $70 \%$ of cases of cervical cancer, including high-grade squamous intraepithelial lesions [16, 25-28]. Several factors (related to a high probability of developing HPV infection) are age at first intercourse and having several sexual partners [28-31].

The main objective of the present study is to determine the prevalence of high-risk HPV in samples of premalignant or malignant cervical cytology in women from the southern region of Ecuador. The kit was able to detect the presence of genotypes $16,18,31,33,35,39,45,51,52,56,58$, and 59 . Papanicolaou test samples were collected according to the Bethesda Classification Diagnosis of any cellular epithelial abnormality. In addition, the possible association of different risk factors with HPV infection was evaluated. Given the high incidence and mortality rate of cervical cancer, and the absence of respective epidemiological studies in this area, the study may contribute to a reduction in its number of deaths.

\section{Population and Methods}

2.1. Population. This observational, cross-sectional, and prospective study was carried out from 2012 to 2013, having been approved by the research committees of the Universidad Técnica Particular de Loja (UTPL) and the Cancer Society of Ecuador (SOLCA) Store core. This study was supported by Universidad Técnica Particular de Loja: Projects PY1019 and PY1620.

A total of 431 women between 17 and 84 years of age used the gynecological services of the SOLCA Hospital, the UTPL Hospital, or the Ecuadorian Family Well-Being Association (APROFE) in the city of Loja, Ecuador, with the intention of learning their Pap test results.

\section{Inclusion Criteria}

(i) Women domiciled in the Province of Loja, Zamora, or El Oro

(ii) Cytological diagnosis of the premalignant or malignant pap smear (ASC-US, ASC-H, LSIL, HSIL, squamous cell carcinoma, AGC, or adenocarcinomas), which had been previously untreated

(iii) Performing the diagnostic colposcopy

(iv) Acceptance of participation in the study through signing an informed consent

\section{Exclusion Criteria}

(i) Women who have given birth or had a Pap smear in the last 3 weeks (ii) Women who underwent colposcopy in the last 6 weeks

(iii) Women who have undergone an invasive procedure in the uterine cervix (conization, biopsy, etc.) in the last 3 months

2.2. Methods. The sociodemographic data (age, place of residence, and marital status) and clinical data (age at first intercourse, number of partners, and history of sexually transmitted infections) of the volunteers were collected by survey.

Patients in the study underwent a cervical scraping, with a sterile cytobrush at the start of the diagnostic-therapeutic colposcopy. Samples were stored in $5 \mathrm{ml}$ of PBS buffer (pH 7.5) between 6 and $8^{\circ} \mathrm{C}$ for a maximum period of 3 days until processing.

DNA extraction was performed with a commercial kit (Pure Link DNA, Invitrogen Co., Grand Isle, NY, USA). The quantity and quality of the DNA were measured by spectrophotometry, using the Nanodrop 200c, Thermo Scientific equipment. It was carried out by examining its optical density of $260 / 280-260 / 230 \mathrm{~nm}$. Between 10 and $100 \mathrm{ng} / \mu \mathrm{L}$ of total DNA extracted for amplification was used.

HPV detection was done by real-time PCR, using the AmpliSens HPV genotype FTR kit (Bretonneux, FR) following the manufacturer's instructions. The kit recognizes 12 high-risk HPV genotypes $(16,18,31,33,35,56,39,45,51,52$, 58 , and 59). Positive and negative controls were used for each reaction. Amplification of the $\beta$-globin gene was a quality control measure of the genetic material.

The data obtained via amplification were analyzed by the Applied Biosystems Fast 7500 Software Detection System (Thermo Fisher Scientific, Waltham, MA, USA). We used a system of presence-absence detection of the genetic material for the virus with 4 fluorophores Cy5 (for $\beta$-globin), FAM (for genotypes 16, 39, 33, and 58), JOE (for genotypes 31, 45,35 , and 52), and ROX (for genotypes 18, 59, 56, and 51). The cycle threshold (CT) was 35, according to the manufacturer's instructions. Samples that exceeded this value were considered positive, by independently observing the behavior of the amplification curve of each genotype.

2.3. Statistical Analysis. The results were analyzed with descriptive statistics, identifying mean values, standard deviation, and/or percentages as appropriate. To assess the association of different risk factors and the presence of HPV infection, the OR (95\% CI) was calculated, considering significant values as $p<0.05$. Calculations were made with these programs: IBM SPSS Statistics (IBM, Armonk, NY, USA) and MedCalc ${ }^{\circledR}$ statistical software (Ostend, BE).

\section{Results}

Characteristics of the 431 participants in the study are shown in Table 1. Furthermore, 64.5\% (278) of the samples tested positive for HPV. Genotypes 16 and 18 were the most prevalent, with 16 being detected in 148 samples (53.2\% of positive samples) and 18 detected in 108 (38.8\%). Another 
TABLE 1: Characteristics of participants.

\begin{tabular}{|c|c|}
\hline Characteristics & Values \\
\hline \multicolumn{2}{|l|}{ Age } \\
\hline Range & $17-84$ \\
\hline Average (SD) & $40.7(13.5)$ \\
\hline \multicolumn{2}{|l|}{ Age of onset of sexual life } \\
\hline Range & $10-45$ \\
\hline Average (SD) & $18.9(4.3)$ \\
\hline Does not answer (\%) & $29(6.7)$ \\
\hline \multicolumn{2}{|c|}{ Number of sexual partners } \\
\hline Range & $1-10$ \\
\hline Average (SD) & $1.6(1.0)$ \\
\hline Does not answer (\%) & $2(0.5)$ \\
\hline \multicolumn{2}{|l|}{ Age at first pregnancy } \\
\hline Range & $11-39$ \\
\hline Average (SD) & $20.8(4.6)$ \\
\hline Does not answer (\%) & $218(50.6)$ \\
\hline \multicolumn{2}{|l|}{ Number of pregnancies } \\
\hline $0(\%)$ & $46(10.7)$ \\
\hline$<3(\%)$ & $159(36.9)$ \\
\hline$\geq 3(\%)$ & $224(52.0)$ \\
\hline Does not answer (\%) & $2(0.5)$ \\
\hline \multicolumn{2}{|l|}{ Condom use } \\
\hline No (\%) & $335(77.7)$ \\
\hline Yes $(\%)$ & $49(11.4)$ \\
\hline Does not answer (\%) & $47(10.9)$ \\
\hline \multicolumn{2}{|l|}{ Civil status } \\
\hline Married (\%) & $285(66.1)$ \\
\hline Divorced (\%) & $21(4.9)$ \\
\hline Single (\%) & $71(16.5)$ \\
\hline Does not answer (\%) & $54(12.5)$ \\
\hline \multicolumn{2}{|l|}{ Level of education } \\
\hline Primary (\%) & $68(15.8)$ \\
\hline High school (\%) & $73(16.9)$ \\
\hline College (\%) & $87(20.2)$ \\
\hline Does not answer (\%) & $203(47.1)$ \\
\hline \multicolumn{2}{|l|}{ Learn about HPV } \\
\hline No (\%) & $331(76.8)$ \\
\hline Yes $(\%)$ & $71(16.5)$ \\
\hline Does not answer (\%) & $29(6.7)$ \\
\hline \multicolumn{2}{|l|}{ Abnormal cytology } \\
\hline AGUS (\%) & $60(13.9)$ \\
\hline ASCUS (\%) & $94(21.8)$ \\
\hline ASC-H (\%) & $21(4.9)$ \\
\hline LSIL (\%) & $158(36.7)$ \\
\hline HSIL (\%) & $83(19.3)$ \\
\hline Cancer (\%) & $15(3.5)$ \\
\hline
\end{tabular}

110 samples (39.6\%) involved a single viral type, while 168 samples $(60.4 \%)$ had multiple infections in samples with up to 7 different genotypes. Table 2 shows the frequency of each type of HPV infection, considering single and multiple displays.
TABLE 2: Frequency of HPV genotypes in positive cases.

\begin{tabular}{llccc}
\hline \multirow{2}{*}{ Genotype } & \multicolumn{2}{c}{ Simple infection } & \multicolumn{2}{c}{ Multiple infection } \\
& $n$ & $\%^{\mathrm{a}}$ & $N$ & $\%^{\mathrm{a}}$ \\
\hline HPV 16 & 52 & 47.3 & 96 & 57.1 \\
HPV 18 & 17 & 15.5 & 91 & 54.2 \\
HPV 31 & 3 & 2.7 & 41 & 24.4 \\
HPV 33 & 1 & 0.9 & 11 & 6.6 \\
HPV 35 & 0 & 0.0 & 11 & 6.6 \\
HPV 39 & 2 & 1.8 & 23 & 13.7 \\
HPV 45 & 0 & 0.0 & 7 & 4.2 \\
HPV 51 & 9 & 8.2 & 72 & 42.9 \\
HPV 52 & 1 & 0.9 & 27 & 16.1 \\
HPV 56 & 5 & 4.6 & 27 & 16.1 \\
HPV 58 & 11 & 10.0 & 63 & 37.5 \\
HPV 59 & 9 & 8.2 & 42 & 25.0 \\
\hline
\end{tabular}

${ }^{\mathrm{a}}$ The percentage is calculated relative to the total positive samples of simple infections (110) and multiple infections (168), respectively.

Considering the cytological diagnosis and presence of HPV, $66.7 \%, 61.7 \%, 52.4 \%, 63.3 \%, 67.5 \%$, and $86.7 \%$ of the samples with AGUS, ASCUS, ASC-H, LIE-AG, and cancer, respectively, had high-risk HPV. The first three HPV genotypes most frequent in each cytologic diagnosis are shown in Table 3.

The association analysis between HPV infection and the risk factors studied, as well as the OR values, is shown in Table 4.

\section{Discussion}

In this first study of its kind for HPV genotypes, we determined the frequency of premalignant and malignant samples of cervical cytology, along with their association with cytological diagnosis and risk factors of infection. The most frequent cytopathology was LSIL at 36.7\%, while cancer cases accounted for $3.5 \%$ of total samples. The prevalence of high-risk HPV in cytological samples was 64.5\%. In Quito, Ecuador, they reported other studies in cytological and/or histologically altered, in which the reported prevalence of HPV was found to be low risk at $67.7 \%$ and $86 \%[32,33]$. In the city of Cuenca, in a study of 500 women from the general population, the prevalence of $25.6 \%$ of HPV for both high and low risk [34] was similar to that reported in Santa Elena. Brown et al. (2009) found [35] a prevalence of 24.2\%. A higher prevalence of HPV with abnormal cytology studies indicates a relationship between the virus and malignant cells.

In the present study, genotypes 16 and 18 were the most frequent, for both simple infections (47.3\% and $15.5 \%$, resp.) and multiple infections (57.1\% and 54.2\%, resp.). Other oncogenic types showed significant incidence. Genotype 58 was presented as the third most common in simple infections (10\%), while 51 ranked third in multiple infections (42.9\%). These results agree with the meta-analysis of Bruni et al. (2010) [36], which reports genotypes 16, 18, 52, 31, and 58 as the most frequent. In the systematic review and metaanalysis of Ciapponi et al. (2011) [37], the prevalence of HPV 
TABLE 3: Frequency of HPV genotypes in all cytological diagnoses.

\begin{tabular}{|c|c|c|c|}
\hline $\begin{array}{l}\text { Cytology (HPV } \\
\text { cases) }\end{array}$ & Genotype & $n^{\mathrm{a}}$ & $\%^{\mathrm{b}}$ \\
\hline \multirow{4}{*}{ AGUS (40) } & HPV 16 & 23 & 57.5 \\
\hline & HPV 18 & 20 & 50.0 \\
\hline & HPV 51 & 11 & 27.5 \\
\hline & Other high-risk $\mathrm{HPV}^{\mathrm{c}}$ & 39 & 97.5 \\
\hline \multirow{4}{*}{$\begin{array}{l}\text { ASCUS (58) } \\
61.70 \%\end{array}$} & HPV 16 & 29 & 50.0 \\
\hline & HPV 18 & 23 & 39.7 \\
\hline & HPV 58 & 15 & 25.9 \\
\hline & Other high-risk HPV & 56 & 96.6 \\
\hline \multirow{4}{*}{$\begin{array}{l}\text { ASC-H (11) } \\
52.38 \%\end{array}$} & HPV 16 & 4 & 36.4 \\
\hline & HPV 18 & 4 & 36.4 \\
\hline & HPV 51 & 4 & 36.4 \\
\hline & Other high-risk $\mathrm{HPV}^{\mathrm{c}}$ & 11 & 100.0 \\
\hline \multirow{4}{*}{$\begin{array}{l}\text { LSIL (100) } \\
63.29 \%\end{array}$} & HPV 16 & 49 & 49.0 \\
\hline & HPV 18 & 35 & 35.0 \\
\hline & HPV 51 & 34 & 34.0 \\
\hline & Other high-risk $\mathrm{HPV}^{\mathrm{c}}$ & 122 & 122.0 \\
\hline \multirow{4}{*}{$\begin{array}{l}\text { HSIL (56) } \\
67.47 \%\end{array}$} & HPV 16 & 35 & 62.5 \\
\hline & HPV 18 & 19 & 33.9 \\
\hline & HPV 51 & 15 & 26.8 \\
\hline & Other high-risk $\mathrm{HPV}^{\mathrm{c}}$ & 43 & 76.8 \\
\hline \multirow{5}{*}{$\begin{array}{l}\text { Cancer (13) } \\
86.67 \%\end{array}$} & HPV 16 & 8 & 61.5 \\
\hline & HPV 18 & 7 & 53.9 \\
\hline & HPV 51 & 3 & 23.1 \\
\hline & HPV 56 & 3 & 23.1 \\
\hline & Other high-risk $\mathrm{HPV}^{\mathrm{e}}$ & 10 & 76.9 \\
\hline
\end{tabular}

${ }^{\mathrm{a}}$ Simple and multiple infections together. ${ }^{\mathrm{b}}$ Percentage in total positive samples of each cytological alteration. ${ }^{\mathrm{c}} \mathrm{HPV} 31,33,35,56,39,59,52,58 .{ }^{\mathrm{d}} \mathrm{HPV} 31,33$, $35,56,39,45,59,51,52 .{ }^{e} \mathrm{HPV} 33,35,39,45,59,52,58$.

in high-grade lesions and cancer of the uterine cervix in Latin America and the Caribbean (analyzing nearly 8,000 samples) was most frequently found in genotypes 16 and 18, followed in descending order by HPV 31, 58, 33, 45, and 52, similar to those obtained in our own study data. Mexico reported the 58 genotype as the second most common after HPV 16 in cervical cancer and abnormal cytology samples [38, 39] and, in Quito, in altered cervical biopsy samples [32].

Studies in Ecuador found genotype 16 as the most common $[32,33,35,40]$, along with results of this investigation. The 18 genotype was not reported as the second most frequent, suggesting that genotypic variability by geographic region and sociodemographic factors had an effect, such that more research is necessary.

Considering the cytological diagnosis, the three most frequent HPV genotypes were 16, 18, and 51 in AGUS, ASC$\mathrm{H}$, LSIL, HSIL, while in cancer and ASCUS the type 58 was the third most frequent, behind genotypes 16 and 18. Some authors suggest that the presence of these genotypes (highgrade lesions) would be more likely to progress to cervical cancer than other HPV types; this is due to the oncogenic potential of these genotypes [41].
There are several risk factors that can influence HPV infection. Some researchers have reported that early onset of sexual life and a higher number of sexual partners significantly increased risk of infection $[42,43]$. Some studies indicated that single or divorced women were more likely to have cervical cancer; however, according to reports in Latin America, men tend to have more than one sexual partner, limiting the use of marital status as a risk factor for contracting this virus [44]. To reduce risk of infection, condom use is recommended for sex, and, in some studies, it could reduce the risk of HPV infection by up to $70 \%[45,46]$. However, there was no significant association in our study for increased risk of infection, given the factors analyzed; this could be due to a possible bias in the information provided by the participants, due to sociocultural factors; in addition, these questions are based on memory and a large number of people did not answer the questions, affecting significantly the results obtained.

In conclusion, in this study, genotypes 16 and 18 were identified as the main types of HPV in the samples analyzed for premalignant and malignant cytology. Genotypes 58 and 51 were presented as the third most frequent type, considering 
TABLE 4: Risk factors and HPV infection.

\begin{tabular}{|c|c|c|c|}
\hline Variables & Positives & Total & OR (IC 95\%) \\
\hline \multicolumn{4}{|c|}{ Age of onset of sexual life } \\
\hline$\geq 21$ & 65 & 97 & \\
\hline$<21$ & 195 & 305 & $0.87(0.5-1.4)$ \\
\hline \multicolumn{4}{|l|}{ Number of pregnancies } \\
\hline$<3$ & 136 & 205 & \\
\hline$\geq 3$ & 141 & 224 & $0.86(0.6-1.3)$ \\
\hline \multicolumn{4}{|c|}{ Number of sexual partners } \\
\hline 1 & 171 & 262 & \\
\hline$>1$ & 105 & 167 & $0.90(0.6-1.4)$ \\
\hline \multicolumn{4}{|l|}{ Condom use } \\
\hline Yes & 35 & 49 & \\
\hline No & 218 & 335 & $0.75(0.4-1.4)$ \\
\hline \multicolumn{4}{|l|}{ Civil status } \\
\hline Married & 185 & 285 & \\
\hline Single-divorced & 56 & 92 & $0.84(0.5-1.4)$ \\
\hline \multicolumn{4}{|l|}{ Level of education } \\
\hline High School-college $^{a}$ & 110 & 160 & \\
\hline Primary & 55 & 68 & $1.92(0.9-3.8)$ \\
\hline \multicolumn{4}{|l|}{ Learn about HPV } \\
\hline Yes & 51 & 71 & \\
\hline No & 211 & 331 & $0.69(0.4-1.2)$ \\
\hline
\end{tabular}



simple and multiple infections, respectively. The data are very similar to those obtained worldwide, again suggesting that the common strategies of sex education and vaccine use as primary preventions could significantly decrease the incidence and mortality rate of cervical cancer in the southern region of Ecuador. Particularly it is considered as potentially beneficial to introduce the integral sexual education in the primary school for 10-11-year-old children because of early beginning of sexual intercourse in the Ecuadorian population.

\section{Conflicts of Interest}

The authors declare no conflicts of interest.

\section{Acknowledgments}

The authors would like to thank Dr. Andrea Ortega Escarabay, Dr. Miguel Bravo González, Dr. Cesar Palacios Soto (SOLCA), Dr. Marco Ayora Apolo (UTPL), and Dr. Lindon Zapata (APROFE). They acknowledge the collaboration of Jorge Torres, Andrés Quito, and David Tapia in the process of these samples. This study was supported by Universidad Técnica Paraticular de Loja: Projects PY1019 and PY1620.

\section{References}

[1] "Cancer Incidence and Mortality Worldwide: IARC Cancer Base No. 11 [Internet]," International Agency for Research on Cancer, http://globocan.iarc.fr.

[2] INEC, "Ecuador: Instituto nacional de estadísticas y censos," http://www.inec.gob.ec/home.
[3] H. Garrido and E. Yunga, Escuela de medicina UTPL, colegio medico de, Escuela de medicina UTPL, colegio medico de Loja, 2010.

[4] G. Shen, J. Cheng, Y. Wang et al., "Viral DNA load of high-risk human papilloma virus is closely associated with the grade of cervical lesions," Int J Exp Med, vol. 7, no. 12, pp. 5826-5831, 2014.

[5] Y.-C. Tu, H.-H. Wang, Y.-J. Lin, and T.-F. Chan, "HPV Knowledge and Factors Associated with Intention to Use Condoms for Reducing HPV Infection Risk among Adolescent Women in Taiwan," Women and Health, vol. 55, no. 2, pp. 187-202, 2015.

[6] G. M. Clifford, J. S. Smith, M. Plummer, N. Muñoz, and S. Franceschi, "Human papillomavirus types in invasive cervical cancer worldwide: a meta-analysis," British Journal of Cancer, vol. 88, no. 1, pp. 63-73, 2003.

[7] M. Salcedo, P. Pina-Sanchez, V. Vallejo-Ruiz et al., "Human papillomavirus genotypes among females in Mexico: A study from the Mexican Institute for Social Security," Asian Pacific Journal of Cancer Prevention, vol. 15, no. 23, pp. 10061-10066, 2014.

[8] J. G. Baseman and L. A. Koutsky, "The epidemiology of human papillomavirus infections," Journal of Clinical Virology, vol. 32, pp. 16-24, 2005.

[9] J. Léniz Martelli, V. Van De Wyngard, M. Lagos, M. I. Barriga, K. Puschel Illanes, and C. Ferreccio Readi, "Early detection of cervical cancer in Chile: Time for change," Revista Medica de Chile, vol. 142, no. 8, pp. 1047-1055, 2014.

[10] X.-C. Wang, L.-Q. Sun, L. Ma et al., "Prevalence and genotype distribution of human papillomavirus among women from Henan, China," Asian Pacific Journal of Cancer Prevention, vol. 15, no. 17, pp. 7333-7336, 2014.

[11] M. L. T. Cossio, L. F. Giesen, G. Araya et al., "Papiloma Virus Humano," Sexologya Medica, no. 2, pp. 81-87, 2012. 
[12] W. Silva-Caso, M. Olivera-Irazábal, P. León-Álvarez et al., "Identification of human papillomavirus as a preventive strategy for cervical cancer in asymptomatic women in the Peruvian Andes," Asian Pacific Journal of Tropical Medicine, vol. 7, no. 1, pp. S121-S126, 2014.

[13] F. X. Bosch, A. N. Burchell, M. Schiffman et al., "Epidemiology and natural history of human papillomavirus infections and type-specific implications in cervical neoplasia," Vaccine, vol. 26, no. 10, pp. K1-K16, 2008.

[14] S. Zaridah, "MOG UKM. A review of cervical cancer research in Malaysia," Med J Malaysia, August 2014.

[15] N. Muñoz, X. Castellsagué, A. B. de González, and L. Gissman, "Chapter 1: HPV in the etiology of human cancer," Vaccine, vol. 24, supplement 3, pp. S1-S10, 2006.

[16] F. X. Bosch, A. Lorincz, N. Muñoz, C. J. L. M. Meijer, and K. V. Shah, "The causal relation between human papillomavirus and cervical cancer," Journal of Clinical Pathology, vol. 55, no. 4, pp. 244-265, 2002.

[17] R. Silva, D. León, P. Brebi et al., "Diagnóstico de la infección por virus papiloma humano en el hombre," Rev Chil Infectol, vol. 30, no. 2, pp. 186-192, 2013.

[18] N. Berthet, M. Falguiéres, C. Filippone et al., "Resequencing microarray technology for genotyping human papillomavirus in cervical smears," PLoS ONE, vol. 9, no. 11, Article ID e109301, 2014.

[19] J. López, G. Ili GC, MP. Brebi et al., "Detección y tipificación de virus papiloma humano en lesiones preneoplásicas de cuello uterino," Rev Med Chil, vol. 138, no. 11, pp. 1343-1350, 2010.

[20] G. Hoste, K. Vossaert, W. Poppe et al., "The Clinical Role of HPV Testing in Primary and Secondary Cervical Cancer Screening," Obstet Gynecol Int, Article ID 610373, p. 2013, 2013.

[21] Z. De Guglielmo, A. Rodríguez, M. Ávila et al., "Virus de papiloma humano y factores de riesgo," Rev Oncol Y Hematol Venez, vol. 22, no. 1, pp. 32-38, 2010, http://www.scielo.org.ve/pdf/rvo/ v22n1/art04.pdf.

[22] M. Jacobs V, PJ. Snijders, TJ. Helmerhorst et al., "PCR-enzyme immunoassay method for rapid detection of 14 high-risk and 6 low-risk human papillomavirus genotypes," J Clin Microbiol, vol. 35, no. 3, p. 791, 1997.

[23] A. Alba, M. Cararach, and C. Rodriguez-Cerdeira, “The Human Papillomavirus (HPV) in Human Pathology: Description, Pathogenesis, Oncogenic Role, Epidemiology and Detection Techniques," The Open Dermatology Journal, vol. 3, no. 2, pp. 90-102, 2009.

[24] E. M. Burd, "Human papillomavirus and cervical cancer," Clinical Microbiology Reviews, vol. 16, no. 1, pp. 1-17, 2003.

[25] S. Srivastava, UP. Shahi, A. Dibya et al., "Distribution of HPV Genotypes and Involvement of Risk Factors in Cervical Lesions and Invasive Cervical Cancer: A Study in an Indian Population," International Journal of Molecular and Cellular Medicine, vol. 3, pp. 61-73, 2014.

[26] S. De Sanjose, WG. Quint, L. Alemany et al., "Human papillomavirus genotype attribution in invasive cervical cancer: a retrospective cross-sectional worldwide study," Lancet Oncol, vol. 11, no. 11, pp. 1048-1056, 2010.

[27] R. Konno, H. Yoshikawa, M. Okutani et al., "Efficacy of the human papillomavirus (HPV)-16/18 AS04-adjuvanted vaccine against cervical intraepithelial neoplasia and cervical infection in young Japanese women: Open follow-up of a randomized clinical trial up to 4 years post-vaccination," Human Vaccines and Immunotherapeutics, vol. 10, no. 7, pp. 1781-1794, 2014.
[28] FE. Campos, "Factores Asociados a Lesiones Cervicales O Presencia Del Virus Del Papiloma Humano En Dos Poblaciones De Factors Associated To Cervical Lesions or Presence of Human Papilloma Virus in Two Populations of Students From Lima," Revista Peruana de Medicina Experimental y Salud Pública, vol. 24, no. 3, pp. 234-239, 2007.

[29] M. J. Khan, P. E. Castle, A. T. Lorincz et al., "The elevated 10-Year risk of cervical precancer and cancer in women with human papillomavirus (HPV) type 16 or 18 and the possible utility of type-specific HPV testing in clinical practice," Journal of the National Cancer Institute, vol. 97, no. 14, pp. 1072-1079, 2005.

[30] A. C. Munk, I. T. Ovestad, E. Gudlaugsson et al., "Consistent condom use increases spontaneous regression in high-risk non-HPV16 but not in HPV16 CIN2-3 lesions, a prospective population-based cohort study," Infect Agent Cancer.

[31] I. Garcés, D. C. Rubio, and I. C. Scarinci, "Factores asociados con el tamizaje de cáncer de cuello uterino en mujeres de nivel socioeconómico medio y bajo en Bogotá," Revista Facultad Nacional de Salud Pública, vol. 30, no. 1, pp. 7-16, 2012.

[32] F. González-Andrade and D. Sánchez, "HPV genotyping in anogenital abnormal samples of Ecuadorian women," Cancer Biomarkers, vol. 5, no. 4-5, pp. 225-232, 2009.

[33] L. Mejía, D. Muñoz, G. Trueba, L. Tinoco, and S. Zapata, "Prevalence of human papillomavirus types in cervical cancerous and precancerous lesions of Ecuadorian women," Journal of Medical Virology, vol. 88, no. 1, pp. 144-152, 2016.

[34] V. Cabrera J, H. Cárdenas O, and C. Campoverde M, "Prevalencia de genotipos del papiloma virus humano en mujeres de la provincia del Azual de Ecuador," Maskana, vol. 6, no. 1, pp. 79-93, 2015.

[35] C. R. Brown, M. L. Leon, K. Muñoz et al., "Human papillomavirus infection and its association with cervical dysplasia in Ecuadorian women attending a private cancer screening clinic," Brazilian Journal of Medical and Biological Research, vol. 42, no. 7, pp. 629-636, 2009.

[36] L. Bruni, M. Diaz, X. Castellsagué, E. Ferrer, F. X. Bosch, and S. De Sanjosé, "Cervical human papillomavirus prevalence in 5 continents: Meta-analysis of 1 million women with normal cytological findings," Journal of Infectious Diseases, vol. 202, no. 12, pp. 1789-1799, 2010.

[37] A. Ciapponi, A. Bardach, D. Glujovsky, L. Gibbons, and M. A. Picconi, "Type-specific HPV prevalence in cervical cancer and high-grade lesions in Latin America and the Caribbean: Systematic review and meta-analysis," PLoS ONE, vol. 6, no. 10, Article ID e25493, 2011.

[38] J. Canul Canche, I. Rosado López, NG. Suárez et al., "High prevalence and low E6 genetic variability of human papillomavirus 58 in women with cervical cancer and precursor lesions in Southeast Mexico," Mem Inst Oswaldo Cruz, vol. 105, no. 2, pp. 144-148, 2010.

[39] FH. Montoya, MM. Ramírez, MM. Morán et al., "Detección de Papilomavirus Humano tipos 16, 18, 35 y 58 en cáncer cervicouterino y lesiones escamosas intraepiteliales de alto grado en el occidente de México: correlación clínico-molecular: correlación clínico-molecular," Ginecol Obs Mex, vol. 69, no. 4, pp. 137-142, 2001.

[40] M. L. Tornesello, L. Buonaguro, S. Izzo et al., "A pilot study on the distribution of human papillomavirus genotypes and HPV-16 variants in cervical neoplastic lesions from Ecuadorian women," Journal of Medical Virology, vol. 80, no. 11, pp. 19591965, 2008. 
[41] G. D. García Muentes, L. K. García Rodríguez, R. I. Burgos Galarraga, F. Almeida Carpio, and J. C. Ruiz Cabezas, "Genotypes distribution of human papillomavirus in cervical samples of Ecuadorian women," Revista Brasileira de Epidemiologia, vol. 19, no. 1, pp. 160-166, 2016, http://www.ncbi.nlm.nih.gov/ pubmed/27167657.

[42] G. M. Clifford, J. S. Smith, T. Aguado, and S. Franceschi, "Comparison of HPV type distribution in high-grade cervical lesions and cervical cancer: A meta-analysis," British Journal of Cancer, vol. 89, no. 1, pp. 101-105, 2003.

[43] A. M. Johnson, C. H. Mercer, S. Beddows et al., "Epidemiology of, and behavioural risk factors for, sexually transmitted human papillomavirus infection in men and women in Britain," Sex Transm Infect [Internet], vol. 88, no. 3, pp. 212-217, 2012, http://www.pubmedcentral.nih.gov/articlerender.fcgi?artid= 3308471\&tool=pmcentrez\&rendertype $=$ abstract.

[44] RL. Winer, JP. Hughes, Q. Feng et al., NIH Public Access. Sex Transm Dis, vol. 10, no. 1, p. 54, 2013.

[45] K. Wellings, M. Collumbien, E. Slaymaker et al., "Sexual behaviour in context: a global perspective," Lancet, vol. 368, no. 9548, pp. 1706-1728, 2006.

[46] R. L. Winer, J. P. Hughes, Q. Feng et al., "Condom use and the risk of genital human papillomavirus infection in young women," New England Journal of Medicine, vol. 354, no. 25, pp. 2645-2654, 2006. 


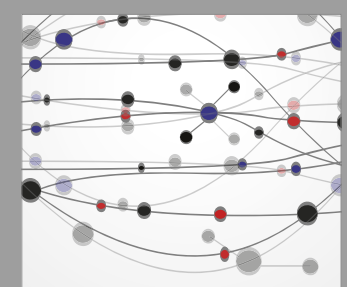

The Scientific World Journal
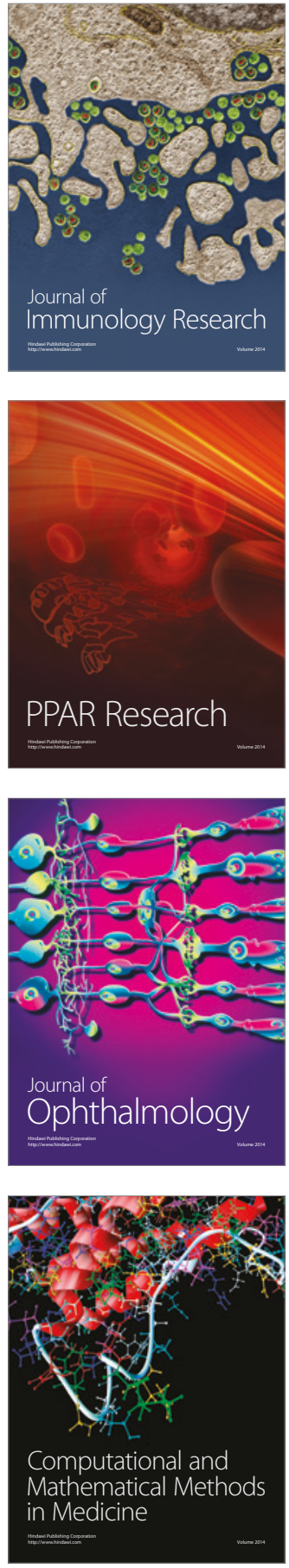



Gastroenterology Research and Practice
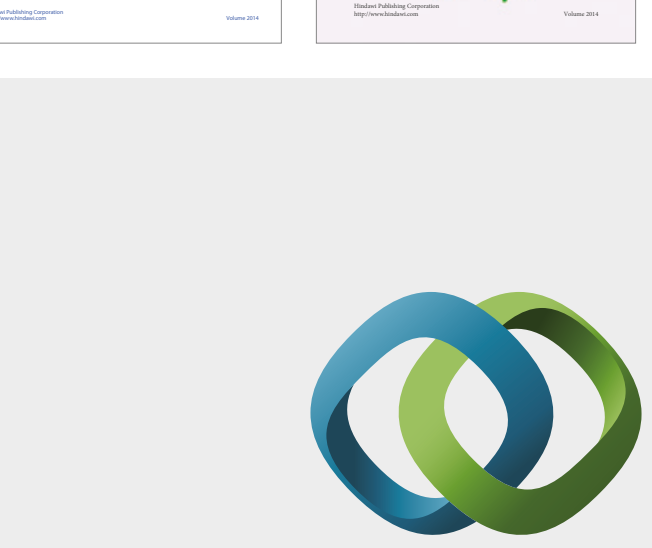

\section{Hindawi}

Submit your manuscripts at

https://www.hindawi.com
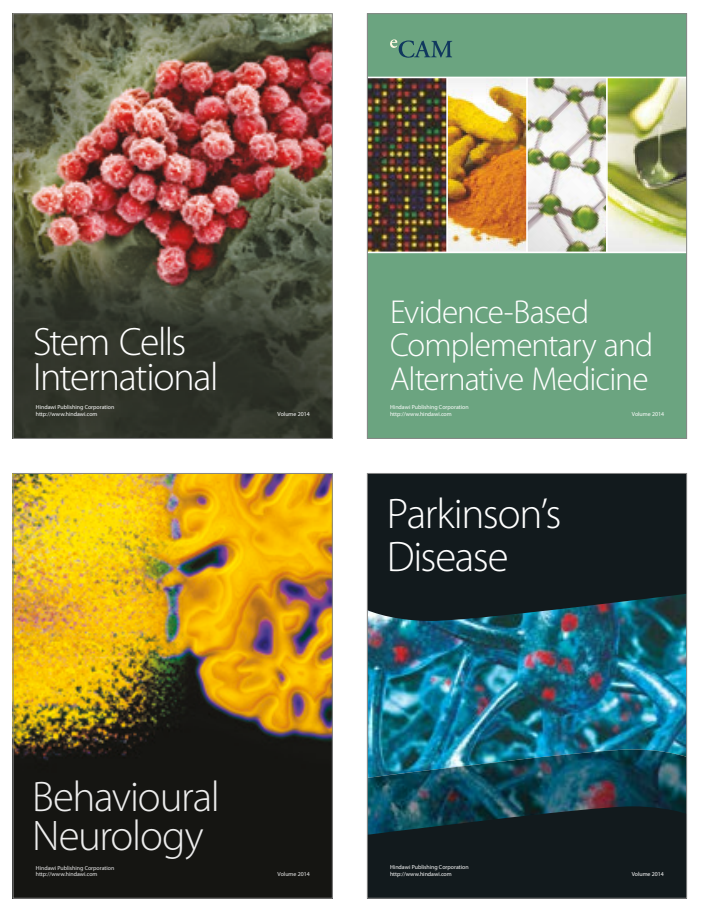
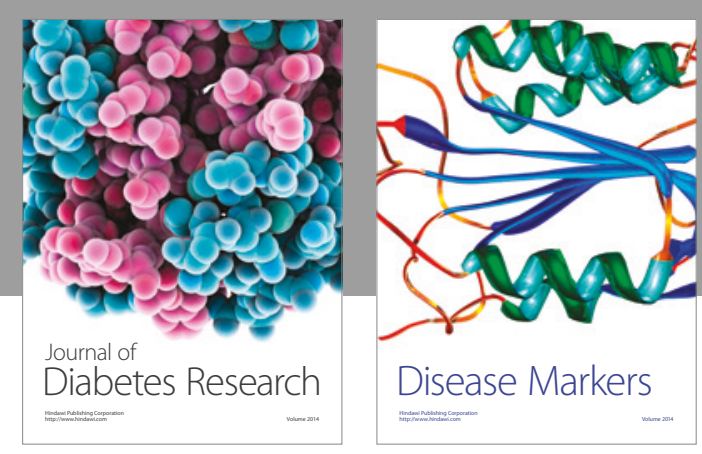

Disease Markers
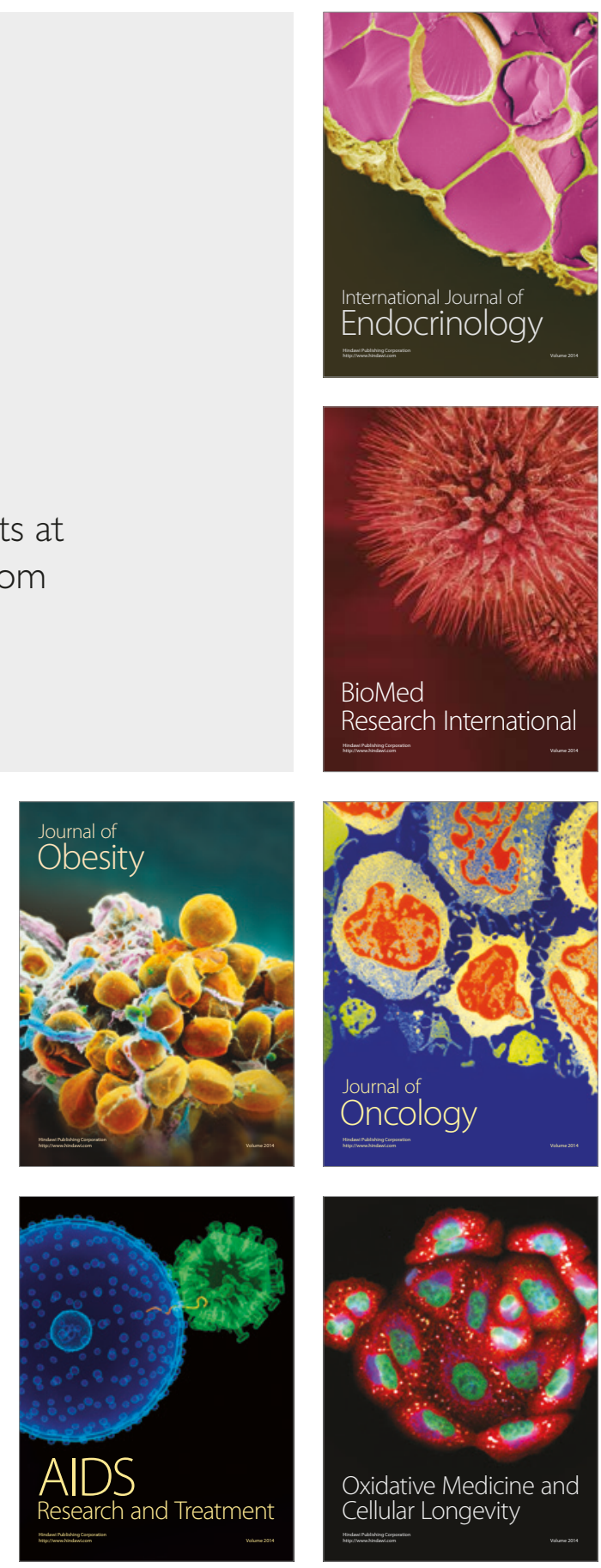